\section{Development and Validation of the Motivation Scale towards Physics Learning}

\section{Elif İnce* iD}

Istanbul University-Cerrahpaşa, Turkey

elifince@istanbul.edu.tr

\section{Hilal Çağap iD}

Istanbul University-Cerrahpaşa, Turkey

hilalcagap@gmail.com

\author{
Yasemin Deneri iD \\ Istanbul University-Cerrahpaşa (Retired), Turkey \\ yderelio@gmail.com
}

\section{Abstract}

This research aims to develop a valid and reliable scale to determine the motivation level of students for learning. Within the scope of this aim, the study utilized Exploratory Factor Analysis (EFA) and Confirmatory Factor Analysis (CFA) with the participation of 1081 undergraduate pre-service science teachers in universities in Turkey. EFA results show the 22 items on the scale group under 3 factors which are Self-Efficacy, Appreciation-Reward, and Value of Learning Physics. The total variance explained by the factors is $53.448 \%$. The Cronbach alpha coefficient was found to be .911 for the whole scale. The findings suggest the Motivation Scale towards Physics Learning (MSPL) is a good tool that researchers and instructors can use to efficiently assess pre-service teachers' motivation to learn physics in universities.

\section{Keywords}

motivation scale development, motivation scale validation, physics education, physics motivation scale.

•Received 6 July $2020 \bullet$ Revised 15 December $2020 \bullet$ Accepted 28 December 2020

\section{Introduction}

The word motivation comes from the root "movere" in Latin, which means "animating" or "moving" (Ruthankoon \& Ogunlana, 2003; Pitrich \& Schunk 1996; Parham, 1988). Motivation is a psychological structure that tries to define the behaviors and efforts shown in life (Watters \& Ginns, 2000). Gage and Berliner (1992) describe the concept of motivation as similar to the relationship between a car's steering and engine, and explain motivation as a force that drives the movement of the individual for behavior. It has also been defined as the determinant of individuals' desire to do something (Richards, Platt, \& Platt, 1992). Maslow (1984) defines motivation as the way people behave as they want and desire according to a certain goal. According to Ryan and Deci (2000a), motivation is defined as taking action to do something. In another definition, motivation is defined as a structure that enables and continues to act for the purpose (Pintrich \& Schunk, 2002; Schunk, 2012). In the literature; motivation is examined in two different groups as the direction of behavior and independent from behavior (Cannon \& Simpson, 1985). While content theories try to identify the factors that initiate motivation by focusing on human needs; process theories focus on how an individual acts, how he/she directs himself, and how he/she controls himself/herself according to behavior change.

\section{Theoretical background}

Learning and motivation are complementary concepts (Pintrich \& Schunk, 1996). Determining how students learn and how they approach the subjects they learn is the focus of education and motivation studies (Tohidi \& Jabbari, 2012). Motivation, which is a psychological concept, affects the learning and performance of students (Schiefele, Krapp \& Schreyer, 1993a; Singh, Graville \& Dika, 2002). It is a starting step for learning (Peklaj \& Levpuscek, 2006). Brophy (1987) states that motivation is an important element that stimulates student's behavior towards learning. According to Ames (1990), learning motivation is the participation of students in teaching activities, the long-term interest in learning and the commitment to their learning. Students' excitement, interest and effort to learn are the main factors of learning motivation (Crump, 1995). It is thought that the motivation level of students to learn a course is specific to that course, and has different motivation levels for different courses (Boekaerts \& Simons, 1995; Urdan, 1997).

Physics is a field of science that provides an understanding of the phenomena in nature (Angell, Guttersrud, Henriksen \& Isnes, 2004). It has an important role in helping students to gain many skills of such as: understanding the events around them; inquiring; critical thinking; awareness about the nature of science; producing knowledge by acquiring scientific process skills; problemsolving; realizing the effects of physics on economy, technology and society; producing useful projects, inventions, and unique designs for society (Ministry of Education-Turkey, 2019). Physics is integrated with all fields of science (Fishbane, Gasiorowicz, \& Thornton, 1996). Today, to be equipped for the generations that need to be well-educated in the light of scientific and technological developments, physics must be taught correctly with daily life applications. Future generations will depend even more heavily on science and technology than we do today. To prepare students for such a future, physics must be taught not just correctly; it must be taught in a way such that students will remember it and be able to apply it to their daily lives. In this respect, the effective learning of physics courses is a necessity for all levels of students (Saleh, 2014). However, physics is seen as a difficult subject matter (De Lozano \& Cardenas, 2002), and students think it is composed of disconnected formulas and laws (Hammer \& Elby, 2003; Guido, 2013). Students' failures in physics and low interest in physics are closely related to their low level of motivation for learning physics.

Copyright $(2020$ Authors. Terms and conditions of Creative Commons Attribution 4.0 International (CC BY 4.0) apply.

* Corresponding author 
When the current studies are examined, we have seen there is a limited number of studies, which are generally focused on the high school level, on the measurement of motivation levels of students for learning physics, and there is limited number of measurement tools developed in order to determine the motivation level of students towards physics learning at university level (Table 1).

Dermitzaki et al. (2013) carried out a Greek adaptation study for physics from Tuan et al. (2005) 's Motivation Questionnaire on science with 350 undergraduates. While adapting this measurement tool, researchers used only "physics" instead of the word "science" in the original scale. The questionnaire was translated and validated by language experts. Factors of the measurement tool were validated as self-efficacy, active learning strategies, the value of science learning, performance, achievement and encouragement in the learning environment. The Cronbach alpha coefficients of these factors were calculated as .82, .79, .52, .78, .69, .68 respectively. The Cronbach's alpha coefficient of the total scale was reported to be .85 .

Saleh (2014) conducted a questionnaire, which was formed by taking opinions of students in order to determine the factors affecting motivation towards physics learning. The data were analyzed quantitatively, and it was indicated that most students had a negative perception of learning Physics in terms of the dimensions of motivation followed by pressure/stress, effort/significance, value/use, interest, understanding, and choice.

Özdemir et al. (2018) developed a measurement tool based on the sub-scales of Tuan et al. (2005), Dede and Yaman (2008), Glynn et al. (2009) research studies to determine the motivation levels of secondary school students for learning physics subjects. The measurement instrument consisted of 38 items. The Cronbach alpha coefficient for the whole scale was reported to be .92 . The Cronbach alpha coefficient values of the sub-factors were determined as .83 for "SelfEfficacy", .77 for "The value of learning Physics", .85 for "Effective learning strategies", .74 for "Achievement Goal", .80 for "Encouragement of the learning environment", .60 for "Communication and collaborative work", and .87 for "Doing research about physics". It was indicated that this scale is suitable to use in research conducted to determine the motivation level of secondary school students for learning physics in this study.
Table 1. Measurement tools and their characteristics.

\begin{tabular}{|c|c|c|c|c|c|}
\hline Researcher(s) & $\begin{array}{l}\text { Field of } \\
\text { Science }\end{array}$ & Participants & $\begin{array}{l}\text { Adaptation/ } \\
\text { Development }\end{array}$ & $\begin{array}{l}\text { Cronbach } \\
\text { Alfa Internal } \\
\text { Consistency } \\
\text { Coefficient } \\
\end{array}$ & $\begin{array}{l}\text { Factors of the Scales and } \\
\text { Cronbach Alfa Internal } \\
\text { Consistency Coefficient } \\
\text { of the Factors } \\
\end{array}$ \\
\hline $\begin{array}{l}\text { Tuan, Chin, \& } \\
\text { Shieh. (2005) }\end{array}$ & Science & $\begin{array}{l}1407 \text { secondary } \\
\text { school students }\end{array}$ & Development & .89 & $\begin{array}{c}\text { Self-efficacy (.78) } \\
\text { Active learning strategies (.84) } \\
\text { The value of learning science (.66) } \\
\text { Performance (.79) } \\
\text { Achievement (.78) } \\
\text { Encouragement in learning environ. (.69) }\end{array}$ \\
\hline $\begin{array}{c}\text { Yılmaz \& Çavaş } \\
\text { (2007) }\end{array}$ & Science & $\begin{array}{l}659 \text { secondary } \\
\text { school students }\end{array}$ & $\begin{array}{l}\text { Adaptation } \\
\text { from Tuan et al. } \\
\text { (2005) }\end{array}$ & .87 & $\begin{array}{c}\text { Self-efficacy }(.71) \\
\text { Active learning strategies (.85) } \\
\text { The value of learning science }(.74) \\
\text { Performance }(.54) \\
\text { Achievement }(.77) \\
\text { Encouragement in learning environ. (.77) }\end{array}$ \\
\hline $\begin{array}{l}\text { Dede \& Yaman } \\
\quad(2008)\end{array}$ & Science & $\begin{array}{l}421 \text { secondary } \\
\text { school students }\end{array}$ & Development & .82 & $\begin{array}{c}\text { Research }(.75) \\
\text { Performance }(.68) \\
\text { Communication (.56) } \\
\text { Cooperative work (.55) } \\
\text { Contribution }(.59)\end{array}$ \\
\hline Ekici (2009) & Biology & $\begin{array}{l}646 \text { high school } \\
\text { student }\end{array}$ & $\begin{array}{l}\text { Adaptation } \\
\text { from Glynn and } \\
\text { Koballa (2006) }\end{array}$ & .87 & $\begin{array}{c}\text { Intrinsic motivation (.85) } \\
\text { Extrinsic motivation (.80) } \\
\text { Interest in learning biology (.83) } \\
\text { Responsibility for learning biology (.86) } \\
\text { Confidence in learning biology (.86) } \\
\text { Responsibility for biology exams (.88) }\end{array}$ \\
\hline $\begin{array}{c}\text { Glynn, } \\
\text { Taasoobshirazi \& } \\
\text { Brickman (2009) }\end{array}$ & Science & $\begin{array}{c}770 \\
\text { undergraduate }\end{array}$ & Development & .91 & $\begin{array}{c}\text { Intrinsic motivation \& personal relevance } \\
(.91) \\
\text { Self-efficacy and assessment Anxiety (.88) } \\
\text { Self-determination (.74) } \\
\text { Career motivation }(.88) \\
\text { Grade motivation }(.55) \\
\end{array}$ \\
\hline Güvendik (2010) & Chem. & $\begin{array}{l}1801 \text { high school } \\
\text { student }\end{array}$ & $\begin{array}{l}\text { Adaptation } \\
\text { from Gylnn et } \\
\text { al. (2009) }\end{array}$ & .88 & $\begin{array}{c}\text { Personal attention }(.83) \\
\text { Self-responsibility }(.80) \\
\text { Self-efficacy }(.79) \\
\text { Intrinsic motivation (.68) } \\
\text { Evaluation anxiety (.58) }\end{array}$ \\
\hline $\begin{array}{l}\text { İlhan, Yıldırım, \& } \\
\text { Yılmaz (2012) }\end{array}$ & Chem. & $\begin{array}{l}308 \text { Pre-service } \\
\text { science teacher }\end{array}$ & $\begin{array}{l}\text { Adaptation } \\
\text { from Glynn et } \\
\text { al. (2009) }\end{array}$ & .82 & $\begin{array}{c}\text { Intrinsic motivation \& personal suitability } \\
(.80) \\
\text { Evaluation anxiety (.66) } \\
\text { Self-determination and Self-efficacy }(.74) \\
\text { Extrinsic motivation }(.61)\end{array}$ \\
\hline Tosun (2013) & Chem. & $\begin{array}{l}306 \text { high school } \\
\text { student }\end{array}$ & $\begin{array}{l}\text { Adaptation } \\
\text { from Gylnn et } \\
\text { al. (2011) }\end{array}$ & .84 & $\begin{array}{c}\text { Score motivation }(.48) \\
\text { Career motivation }(.85) \\
\text { Self-efficacy }(.80) \\
\text { Self-recognition }(.71) \\
\text { Intrinsic motivation }(.34) \\
\end{array}$ \\
\hline
\end{tabular}




\begin{tabular}{|c|c|c|c|c|c|}
\hline Tosun (2013) & Chem. & $\begin{array}{c}266 \\
\text { undergraduate }\end{array}$ & $\begin{array}{l}\text { Adaptation } \\
\text { from Gylnn et } \\
\text { al. (2011) }\end{array}$ & .83 & $\begin{array}{c}\text { Score motivation }(.80) \\
\text { Self-efficacy }(.74) \\
\text { Self-recognition }(.75) \\
\text { Intrinsic motivation }(.66) \\
\end{array}$ \\
\hline $\begin{array}{l}\text { Dermitzaki, } \\
\text { Stavroussi, } \\
\text { Vavougios, \& } \\
\text { Kotsis (2013) }\end{array}$ & Physics & $\begin{array}{c}350 \\
\text { undergraduate }\end{array}$ & $\begin{array}{c}\text { Adaptation } \\
\text { from Tuan et al. } \\
\text { (2005) }\end{array}$ & .85 & $\begin{array}{c}\text { Self-efficacy (.82) } \\
\text { Active learning strategies (.79) } \\
\text { The value of learning science (.52) } \\
\text { Performance (.78) } \\
\text { Achievement (.69) } \\
\text { Encouragement in the learning environ. (.68) }\end{array}$ \\
\hline Saleh (2014) & Physics & $\begin{array}{l}337 \text { high school } \\
\text { student }\end{array}$ & $\begin{array}{c}\text { Adaptation } \\
\text { from Ryan et al. } \\
(1994)\end{array}$ & Unspecified & Unspecified \\
\hline $\begin{array}{c}\text { Aydın, Yerdelen, } \\
\text { Yalmancı, \& } \\
\text { Göksu (2014) } \\
\end{array}$ & Biology & $\begin{array}{l}479 \text { high school } \\
\text { student }\end{array}$ & Development & Unspecified & $\begin{array}{l}\text { Intrinsic motivation }(.88) \\
\text { Unmotivated state }(.84) \\
\text { External motivation-career }(.84) \\
\text { External motivation-social }(.74) \\
\end{array}$ \\
\hline $\begin{array}{l}\text { Fortus \& Vedder- } \\
\text { Weiss (2014) }\end{array}$ & Science & $\begin{array}{l}2958 \text { secondary } \\
\text { school students }\end{array}$ & Development & .83 & One-dimensional \\
\hline $\begin{array}{l}\text { Mubeen \& Reid } \\
\quad \text { (2014) }\end{array}$ & Science & $\begin{array}{l}600 \text { secondary } \\
\text { school students }\end{array}$ & $\begin{array}{c}\text { Adaptation } \\
\text { from Glynn and } \\
\text { Koballa (2006) }\end{array}$ & - & - \\
\hline $\begin{array}{c}\text { Önen \& Ulusoy } \\
(2014)\end{array}$ & Chem. & $\begin{array}{c}525 \text { high school } \\
\text { student }\end{array}$ & Development & .91 & Interest (.84) Benefit (.80) Performance (.81) \\
\hline Rodil (2014) & Chem. & $\begin{array}{c}127 \\
\text { undergraduate }\end{array}$ & Development & 90 & $\begin{array}{c}\text { Selection behavior }(.74) \\
\text { Permanent behavior }(.84) \\
\text { Studying approaches and strategies }(.84) \\
\text { Flexible behavior }(.71)\end{array}$ \\
\hline $\begin{array}{l}\text { Çetin-Dindar \& } \\
\text { Geban (2015) }\end{array}$ & Chem. & $\begin{array}{l}1354 \text { high school } \\
\text { student }\end{array}$ & $\begin{array}{c}\text { Adaptation } \\
\text { from Glynn ve } \\
\text { Koballa (2006) }\end{array}$ & .93 & $\begin{array}{l}\text { Self-efficacy in learning chemistry (.91) } \\
\text { Concern for chemistry exams (.59) } \\
\text { External motivation for learning chem. (.90) } \\
\text { Intrinsic motivation for learning chem. (.63) }\end{array}$ \\
\hline $\begin{array}{c}\text { Erdoğan, Çakır, } \\
\text { Gürel \& Şeker } \\
\text { (2015) }\end{array}$ & Science & $\begin{array}{l}220 \text { secondary } \\
\text { school students }\end{array}$ & $\begin{array}{l}\text { Adaptation } \\
\text { from Fortus ve } \\
\text { Vedder-Weiss } \\
\text { (2014) } \\
\end{array}$ & .87 & One-dimensional \\
\hline $\begin{array}{l}\text { Liu, Ferrell, } \\
\text { Barbera, \& Lewis } \\
\text { (2017) }\end{array}$ & Chem. & $\begin{array}{c}238 \\
\text { undergraduate }\end{array}$ & $\begin{array}{l}\text { Adaptation } \\
\text { based on self- } \\
\text { determination } \\
\text { theory }\end{array}$ & - & $\begin{array}{c}\text { Unmotivated state }(.86) \\
\text { External regulation }(.90) \\
\text { Internal regulation }(.83) \\
\text { Defined regulation }(.79) \\
\text { Experience }(.88) \\
\text { Achievement }(.90) \\
\text { Knowledge }(.84)\end{array}$ \\
\hline $\begin{array}{l}\text { Özdemir, Kural \& } \\
\text { Kocakülah (2018) }\end{array}$ & Physics & $\begin{array}{l}492 \text { high school } \\
\text { student }\end{array}$ & $\begin{array}{l}\text { Adaptation } \\
\text { based on Tuan } \\
\text { et al. (2005), } \\
\text { Dede and } \\
\text { Yaman (2008), } \\
\text { Glynn et al. } \\
\text { (2009) }\end{array}$ & .92 & $\begin{array}{c}\text { Self-efficacy }(.83) \\
\text { The value of learning physics }(.77) \\
\text { Effective learning strategies }(.85) \\
\text { Achievement }(.74) \\
\text { Learning environment }(.80) \\
\text { Communication and collaborative work (.60) } \\
\text { Physics-related research (.87) }\end{array}$ \\
\hline
\end{tabular}

\section{Present Study}

When the reforms realized in education around the world are examined, it is seen that is necessary to train new generations who can integrate science, mathematics, technology and engineering at each level of education, and STEM education practices are continuing rapidly (Lai, 2018). In this context, pre-service science teachers should be well educated and well-equipped teachers who can integrate science with other fields. In STEM education, the relationship and integration of physics courses with other courses are very important (Lai, 2018). But the studies show that pre-service science teachers' physics achievement and attitudes towards physics are quite low (Colclough, Lock, \& Soares, 2011; Cebesoy, 2013; Lynch, 2006, 2010).

The main purpose of this study was to investigate whether the Motivation Scale towards Physics Learning is a valid and reliable measurement tool. The research questions investigated in this study were as follows:

-To what extent is this Motivation Scale towards Physics Learning valid?

-To what extent is this Motivation Scale towards Physics Learning reliable?

In the literature, it has been identified there is a limited number of studies that are generally focused on the secondary level on the measurement of motivation levels of students for learning physics, and a limited number of measurement tools developed to determine the motivation level of students towards physics learning at the university level. In this context, this research focused on developing a valid and reliable scale to determine the motivation levels of pre-service science teachers towards physics learning.

\section{Method}

In this section, we present in detail the process of the development of the Motivation Scale towards Physics Learning (MSPL) developed for pre-service science teachers, and the steps of validity and the reliability of the scale.

\section{Questionnaire}

The scale was formed as a 5-point Likert type. The options and scores of the items in the scale were "Strongly Disagree =1", "Disagree = 2 ", "Undecided = 3", "Agree = 4 " and" Strongly Agree $=5$. The reverse items were coded as "Strongly disagree $=5$ ", "Disagree $=4$ ", "Undecided $=3$ ", "Agree = 2" and "Strongly agree = 1". The scale was developed on the basis of literature, and the factors affecting the motivation levels of the students were taken into consideration such as; self-efficacy, learning strategies, performance, achievement, learning environment, fear of failure, fear of exams, self-confidence, self-regulation, motivation to pass the course, career, selfrecognition, the value of physics learning, intrinsic motivation, extrinsic motivation and nonmotivational state. The high number of these factors also affected the number of items created for the item pool. 115 items were formed, including 21 reverse items for the raw scale. The items 
in the pool were examined by two physics educators, two assessment and evaluation experts and one language expert. According to expert evaluations, 41 inappropriate items were removed from the item pool, and the number of items was reduced to 74 . The measuring instrument for the pilot application thus contains 9 reverse items. The scale was applied to 32 pre-service science teachers. It was seen that there was no negative feedback from the students in this process where the intelligibility of the items was measured.

The application of the scale which consisted of 74 items was carried out with 631 pre-service science teachers. As a result of the first analyses, because of low factor loadings, it was decided to remove 13 more items at this stage. EFA was performed with 61 items. According to the EFA results, 39 more items were removed from the measurement tool at this stage. In the last case, it was determined that scale consisted of 22 items and had a 3 sub-factors. CFA was carried out with the participation of 450 pre-service science teachers. For the reliability, 42 pre-service science teachers were enrolled in the test-retest application.

Statistical Analysis

SPSS 21.0 was used for item analysis, exploratory factor analysis and test-retest reliability analysis, and LISREL 8.71 was used for confirmatory factor analysis.

Participants

The participants were determined as pre-service science teachers who had taken/ were taking the physics course in the 18-21 age range. Content validity was provided with 32 first-year pre-service science teachers ( 28 girls, 4 boys) who were enrolled in the department of science education in a state university education faculty in Istanbul in the 2017-2018 academic year.

In order to gather the data for EFA, we used 682 (1st, 2nd, 3rd, and 4th year) pre-service science teachers who were enrolled in the department of science education in state universities education faculty in Turkey in 2017-2018 academic year. It was decided not to use 51 inappropriate data, and EFA analysis was performed with the data of 631 (538 girls, 93 boys) pre-service science teachers.

For CFA, we used 466 (1st, 2nd, 3rd, and 4th -year) pre-service science teachers who were enrolled in the department of science education in two different state universities education faculty in Istanbul and Erciyes in Turkey in the 2018-2019 academic year. CFA analysis was performed with the data of 450 (398 girls, 52 boys) pre-service science teachers.

For the test - re-test application, we used 42 (36 girls, 6 boys) second-year pre-service science teachers who were enrolled in the department of science education in a state university education faculty in Istanbul in the 2018-2019 academic year. All the mentioned applications of the MSPL were carried out by the researchers in the classroom environment where the pre-service science teachers could answer individually.

\section{Results}

In this section, the results of the analysis of the validity and reliability are presented in detail.

\section{Validity Analysis}

Content V alidity: In line with the conceptual framework of motivation, the item pool consisting of 115 items, 21 of which are reverse, was prepared by considering specified literature and student interviews.

The item pool was examined by two assessment and evaluation experts, two physics educators experts and one language expert according to the conceptual framework for compliance with the expressions used in physics, grammar and style of expression. As a result of these evaluations, it was decided that 41 items should be removed from the item pool. With this 74 -item initial assessment, the instrument was piloted to 32 (28 girls, 4 boys) pre-service science teachers in the second year of the 2017-2018 academic year at a state University Faculty of Education in Istanbul. No negative feedback was received regarding the items on the scale from pre-services. It was concluded that the items were clear and understandable by the pre-service science teachers. The scale became the first version, with 74 items, nine of which were reversed. In this context, it was seen that the scale meets the scope validity criteria.

\section{Exploratory Factor Analysis}

EFA was performed with 74 items by using the data obtained from 631 pre-service science teachers. In this context, it was determined that the Cronbach alpha coefficient of the scale was .949 and the Cronbach alpha value was .955. Before the Factor Analysis, Item Total and Cronbach Alpha values were calculated separately for all items to remove inappropriate items. It was determined that mean values of the items were between 2.49 and 4.42 , and the standard deviation values were between .824 and 2.248. To further increase the corrected item-total correlation and the Cronbach alpha internal consistency coefficient values, 13 items which were included in all the reverse items were removed from the scale. The 61 -item structure of the scale was examined, and it was found that the Cronbach alpha coefficient of 61 items was .967, and the Cronbach alpha value based on standardized items was 967.

EFA was performed using 61 items. A criterion used to test the suitability of the data structure for factor analysis was the Kaiser-Meyer-Olkin (KMO) test. Also, the Bartlett for Sphericity test was used to determine the suitability of the data for factor extraction.

As shown in Table 2, the KMO value of scale items was 0.965 and the Bartlett test of sphericity was found to be .00 . For the significance level, the Bartlett test of sphericity value should be less than .05. The KMO value should be above .60 according to Pallant (2001). Hutcheson and Sofroniou (1999) who indicated that if the KMO value is between .70 and .80, the sample is good; between .80 and .90 , the sample is very good, and .90 and above, the sample is excellent. The results of both KMO and Bartlett values show that data are suitable for factor analysis. Another 
criterion for the suitability of factor analysis is the Anti-image correlation variable value. Antiimage correlation variable values are expected to be greater than .50 (Field, 2000). Anti-image correlation item values of the measurement tool were found to vary between .934 and.979, and these values were found to be significant and sufficient for factor analysis.

Table 2. KMO and Bartlett of Sphericity test results of 61 -item form of the scale

\begin{tabular}{ccc}
\hline $\begin{array}{c}\text { KMO Measure of Sampling } \\
\text { Adequacy }\end{array}$ & & .965 \\
\hline Bartlett Test for Sphericity & Approx. Chi-Square & 19564.320 \\
& $\mathrm{df}$ & 1830 \\
& Sigma & .000 \\
\hline
\end{tabular}

To determine the factor structure of the measurement tool, a principal component analysis was performed. As a result of the analysis, nine factors with an eigenvalue greater than 1 were determined, and this structure explained $55.899 \%$ of the total variance of the scale. Henson and Roberts (2006) stated that total variance should be $52 \%$ and above in the scale development studies. In this context, the total variance value explained by the scale is at an appropriate value.

To check the factor load values and overlapping conditions of each item, the Rotated Component Matrix Table was examined, and it was found that many items overlapped, or some items do not have appropriate values in any factor. Factor load values were taken as .32 and above as the criterion (Seçer, 2015). At this stage, 39 items which did not have appropriate values in any of the factors or showed an overlap in more than one factor were excluded from the scale, and the components analysis was performed again. The final version of the scale was found to have 22 items and 3 factors. When Table 3 is examined, it can be seen that a 3 -factor structure explained $53.448 \%$ of the total variance (Table 3 ).

Table 3. Total variance explanation of 22-item scale.

\begin{tabular}{|c|c|c|c|c|c|c|c|c|c|}
\hline \multirow[b]{2}{*}{ Factors } & \multicolumn{3}{|c|}{ Initial Eigenvalues } & \multicolumn{3}{|c|}{$\begin{array}{l}\text { Extraction Sums of Squared } \\
\text { Loadings }\end{array}$} & \multicolumn{3}{|c|}{$\begin{array}{c}\text { Rotation Sums of Squared } \\
\text { Loadings }\end{array}$} \\
\hline & Total & $\%$ of Varianc & $\begin{array}{c}\text { Cumulative } \\
\%\end{array}$ & Total & $\begin{array}{c}\text { \% of } \\
\text { Variance } \\
\end{array}$ & Cumulative \% & Total & $\begin{array}{c}\% \text { of } \\
\text { Variance } \\
\end{array}$ & Cumulative \% \\
\hline 1 & 7.809 & 35.497 & 35.497 & 7.809 & 35.497 & 35.497 & 5.708 & 25.946 & 25.946 \\
\hline 2 & 2.733 & 12.424 & 47.921 & 2.733 & 12.424 & 47.921 & 3.293 & 14.970 & 40.915 \\
\hline 3 & 1.216 & 5.527 & 53.448 & 1.216 & 5.527 & 53.448 & 2.757 & 12.533 & 53.448 \\
\hline 4 & .845 & 3.843 & 57.291 & & & & & & \\
\hline 22 & .301 & 1.370 & 100.000 & & & & & & \\
\hline
\end{tabular}

The ScreePlot was also examined for factor number verification, and the scale was found to have a 3-factor structure with an eigenvalue greater than 1 and a steep slope (Figure 1).

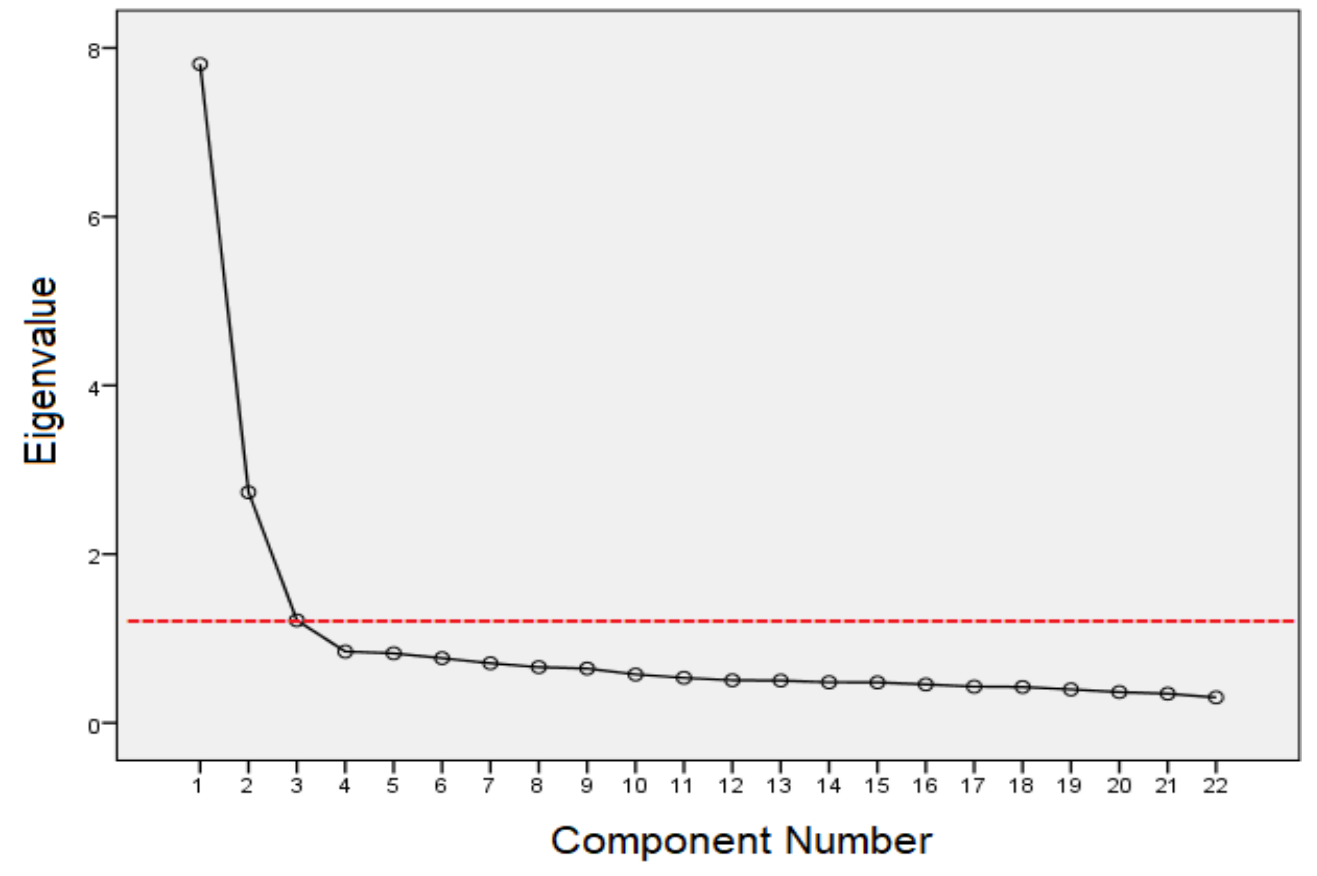

Figure 1. ScreePlot.

The three factors were rotated around the origin axes. A varimax rotation was used to produce the factor loadings of the components. A direct oblimin rotation was also used with similar results. The Rotated Component matrix and factor loading were shown in Table 4. When the Rotated Component matrix table was examined; it was seen that the first factor consisted of 13 items, the second factor consisted of 5 items and the third factor consisted of 4 items. Factor loads of the items for the first factor varied between .555 and .744 , in the second factor varied between .667 and.821, and in the third factor varied between .579 and .778 (Table 4). 
Table 4. Rotated component matrix and factor loading.

\begin{tabular}{cccc}
\hline Item & \multicolumn{3}{c}{ Factor Loading } \\
\cline { 2 - 4 } Number & $\mathbf{1}$ & $\mathbf{2}$ & $\mathbf{3}$ \\
\hline 15 & .744 & & \\
11 & .693 & & \\
19 & .684 & & \\
8 & .672 & & \\
13 & .657 & & \\
6 & .656 & & \\
18 & .639 & & \\
16 & .629 & & \\
22 & .628 & & \\
2 & .623 & & \\
21 & .597 & & \\
5 & .579 & & \\
14 & .555 & & \\
4 & & .821 & \\
12 & & .775 & \\
1 & & .735 & \\
9 & & .697 & \\
20 & & .667 & \\
10 & & & .778 \\
3 & & & .731 \\
7 & & & .687 \\
17 & & & .579 \\
\hline
\end{tabular}

Naming of Factors

When the items distributed to the factors were examined; it was seen that the first factor is associated with Self-Efficacy, the second factor is associated with Appreciation-Reward, and the third factor is associated with the Value of Learning Physics.

Self Efficacy: According to Bandura (1977), self-efficacy is expressed as the belief in the ability of an individual to plan and perform the behaviors that an individual needs to manage future situations. Self-efficacy is central to the belief that an individual can perform a particular task. If the individual's self-efficacy is high, he/she will benefit from affective and cognitive processes. Self-efficacy, which is one of the fundamental concepts of Bandura's social cognitive theory, is the most important motivating factor behind the actions of individuals. Increasing self-efficacy allows increasing the strength and determination of the occurrence of high performance (Arseven, 2016).

Appreciation-Reward: The reward is an external stimulus that encourages the individual to do a behavior. These rewards can be tangible or intangible (Eren, 2004). According to the self- determination theory, an individual with external motivation performs a behavior in order to gain social approval or reward (Horn, 2000). In this context, the individual's desire to hear appreciative words can be an intangible reward. An appreciation-reward is thought to be the external stimulus of the concept of motivation.

Value of Learning Physics: During education, we come across many questions from students about why they learn the subjects, where to use what they have learned and what is the connection between knowledge and real life. This situation shows that students want to learn to what extent daily life and scientific knowledge are related to each other (Pekdağ, Azizoğlu, Topal, Ağalar \& Oran, 2013). To fully learn a concept, the student must apply it in daily life (Smith \& Siegel, 2004). In other words, when an individual thinks that a concept to be learned is valuable for herself/himself and her/his environment, she/he wants to obtain that information. Therefore, an individual's association with physics and daily life makes her/him think that learning physics is valuable. Stylianides and Stylianides (2008) indicated that real-life contexts are motivating for students. Elmas (2012) found that lessons associated with daily life are better liked and motivate the students.

\section{Confirmatory Factor Analysis}

According to the results of exploratory factor analysis, it was determined that the measurement tool consisted of 22 items and had a 3-factors structure. The lowest score that can be obtained from the scale is 22 and the highest score is 110 . In order to perform the CFA of this final version of MSPL, data from 450 pre-service science teachers were used. The results were analyzed by using the LISREL 8.71 program. In the CFA, some reference values are used to demonstrate the statistical suitability of the model. In this study; obtained values of the ratio of criteria, which are chi-square to freedom degree $\left(\chi^{2} / d f\right)$, Goodness of Fit Index (GFI), Adjusted Goodness of Fit Index (AGFI), Comparative Fit Index (CFI), Incremental Fit Index (IFI) and Root Mean Squared Error (RMSEA) were presented (Table 5).

Table 5. Fit criteria according to the index of fit used in structural equation model.

\begin{tabular}{cccc}
\hline Criteria & Good Fit & Acceptable & Obtained Values \\
\hline$p$ & $.05 \leq p \leq 1.00$ & $.01 \leq p \leq .05$ & .000 \\
$\chi^{2} / d f$ & $0 \leq \chi^{2} / d f \leq 2$ & $2 \leq \chi^{2} / d f \leq 3$ & 2.416 \\
RMSEA & $0 \leq \mathrm{RMSEA} \leq .05$ & $.05 \leq \mathrm{RMSEA} \leq .08$ & .047 \\
$(\mathrm{RMSEA}<.05)$ & $0.01 \leq p \leq 1.00$ & $.05 \leq p \leq .10$ & .78 \\
$\mathrm{SRMR}$ & $0 \leq \mathrm{SRMR} \leq .05$ & $.05 \leq \mathrm{SRMR} \leq .10$ & .051 \\
$\mathrm{NFI}$ & $.95 \leq \mathrm{NFI} \leq 1.00$ & $.90 \leq \mathrm{NFI} \leq .95$ & .97 \\
NNFI & $.97 \leq \mathrm{NNFI} \leq 1.00$ & $.95 \leq \mathrm{NNFI} \leq .97$ & .98 \\
CFI & $.97 \leq \mathrm{CFI} \leq 1.00$ & $.95 \leq \mathrm{CFI} \leq .97$ & .98 \\
GFI & $.95 \leq \mathrm{GFI} \leq 1.00$ & $.90 \leq \mathrm{GFI} \leq .95$ & .93 \\
AGFI & $.90 \leq \mathrm{AGFI} \leq 1.00$ & $.85 \leq \mathrm{AGFI} \leq .90$ & .92 \\
IFI & $.95 \leq \mathrm{FII} \leq 1.00$ & $.90 \leq \mathrm{IFI} \leq .95$ & .98 \\
\hline
\end{tabular}

IJPCE - International Journal of Physics and Chemistry Education, 12(4), 61-74, 2020 
According to the CFA, the $\chi^{2}$ value was found to be 492.88 , the $\mathrm{df}$ value was found to be 204 and the p-value was found to be .000 . Since the value of $\chi^{2}$ is affected by the sample size, the $\chi^{2} / d f$ value was examined. The fact that this ratio had a value less than or equal to 3 indicated that the model shows a good fit (Marsh \& Hocevar, 1985; Sümer, 2000; Klassen, Bong, Usher, Chong, Huan, Wong \& Georgiou, 2009). The value of $\chi^{2} / d f$ was determined as 2.41, which indicated that the model had a very high fit. Another criterion for model compliance is the RMSEA value. The RMSEA value must be less than .06 (Hu \& Bentler, 1999; Sümer, 2000). The value of RMSEA was determined as .047 , which indicated that the model had a very high fit. NFI, NNFI, CFI, GFI, AGFI and IFI values above .90 are acceptable criteria. These values were found to be $.97, .98, .98, .93, .92$ and .98 respectively in this study. It was seen these values were in the good fit range (MacCallum, Browne, \& Sugawara, 1996; Hu \& Bentler, 1999).

When the $t$ values of the scale items were examined, it was seen that the $t$ value that indicates whether each item is related to its size varied between 12.21 and 16.94, and was above the threshold value. The threshold value has been accepted as 1.96 (for .05 significance level) or 2.576 (for .01 significance level) (Şimşek, 2007). This result showed that items in this measurement tool have a significant relationship with the factor to which they were assigned (Table 6).

$\mathrm{R} 2$, which is another important criterion within the context of CFA, expresses the explained variance of each observed variable and reveals how much this variable refers to the latent variable (Simșek, 2007). When Table 6 is examined, it can be seen that R2 values of the variables vary between .28 and .65 . According to R2 values, the variable that provides the highest contribution to the measuring instrument is .65 (M4), and the variable that provides the least contribution is .28 (M18).

Table 6. Standardized regression coefficients, latent variable and t-values of the scale.

\begin{tabular}{|c|c|c|c|c|c|c|c|c|c|}
\hline Sub-Factors & Item \# & $\lambda$ & $t$ & $R^{2}$ & Sub-Factors & Item \# & $\lambda$ & $t$ & $R^{2}$ \\
\hline \multirow{9}{*}{ Self-Efficacy } & 14 & .56 & 16.73 & .35 & \multirow{5}{*}{$\begin{array}{l}\text { Appreciation- } \\
\text { Reward }\end{array}$} & 20 & .65 & 15.91 & .39 \\
\hline & 21 & .58 & 16.10 & .46 & & 1 & .46 & 14.72 & .51 \\
\hline & 19 & .64 & 16.20 & .44 & & 12 & .33 & 13.86 & .57 \\
\hline & 11 & .47 & 15.81 & .50 & & 4 & .28 & 12.21 & .65 \\
\hline & 16 & .89 & 16.94 & .29 & & 9 & .43 & 15.41 & .44 \\
\hline & 8 & .68 & 16.37 & .42 & \multirow{4}{*}{$\begin{array}{l}\text { Value of } \\
\text { Learning } \\
\text { Physics }\end{array}$} & 10 & .32 & 13.77 & .55 \\
\hline & 22 & .53 & 15.77 & .49 & & 3 & .31 & 12.68 & .61 \\
\hline & 13 & .69 & 16.04 & .45 & & 7 & .38 & 13.75 & .55 \\
\hline & 6 & .64 & 16.37 & .42 & & 17 & .60 & 15.92 & .37 \\
\hline
\end{tabular}

$16.37 \quad .42$

$16.57 \quad .38$

$16.41 \quad .41$

\begin{tabular}{ll}
$16.20 \quad .44$ \\
\hline
\end{tabular}

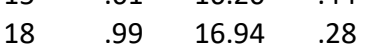

The factor structure and path diagram results were also presented in Figure 2. According to the results of the CFA analysis; it was found that the obtained fit indices were acceptable, and this structure was confirmed as the three-factor structure of the MSPL.

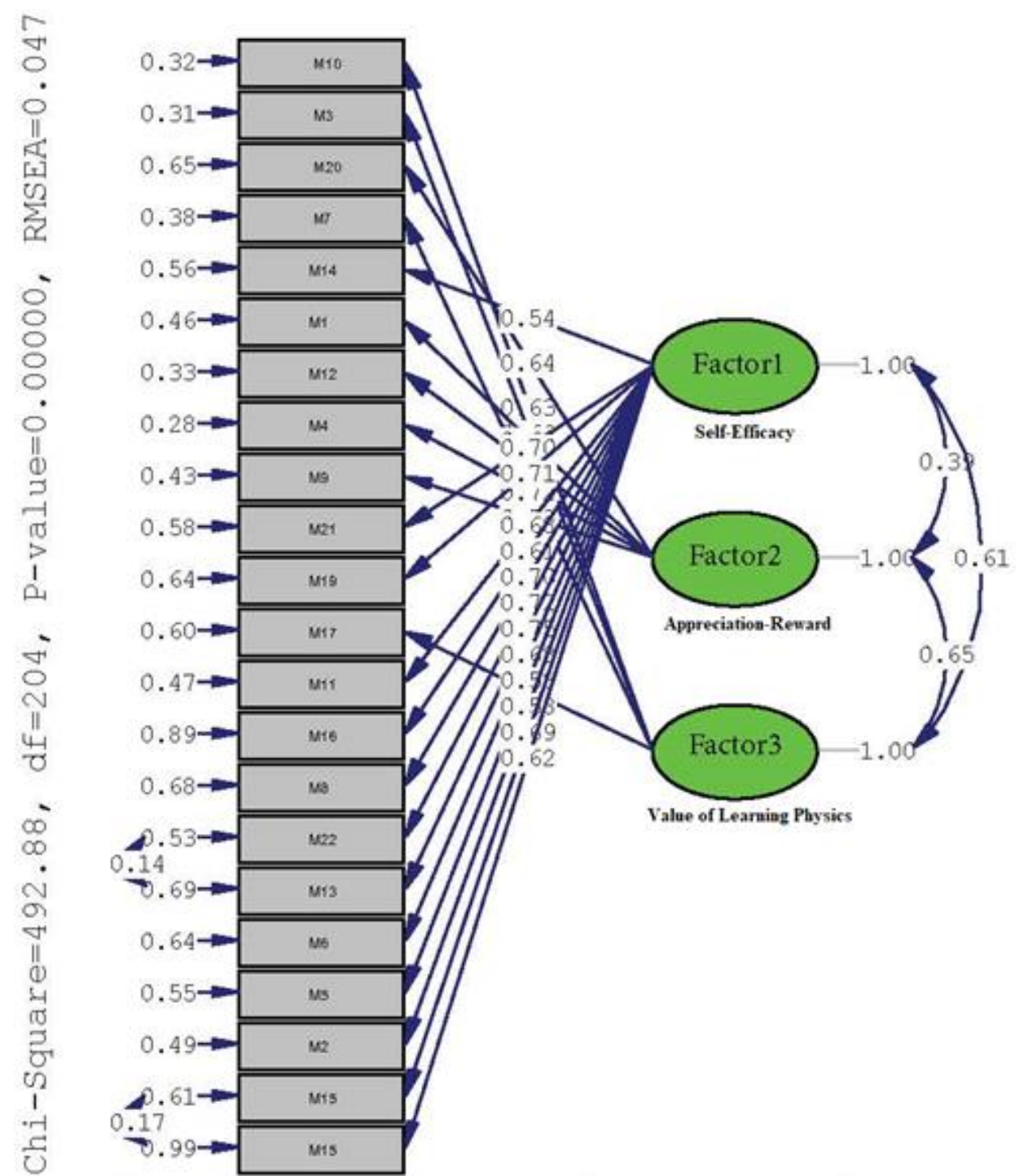

Figure 2. Path diagram of confirmatory factor analysis. 


\section{Reliability Analysis}

For the reliability of the MSPL, the mean value, standard deviation, item-total, corrected itemtotal and Cronbach alpha of item deleted values were calculated and presented in Table 7 for each item. When these results were examined, it was found that the mean scores of the items ranged between 3.1 and 4.4; the standard deviation value of the scale is 12.89 . The Pearson correlation coefficient was calculated to examine the relationship between each item and the whole scale. These values varied between .430 and .716; it was seen that each item had a medium and high correlation with the whole scale. When Corrected item-total Correlation results were examined, it was found that values varied between .401 and .695. These values indicated that each item had a medium and high correlation with the whole scale. In addition, the Cronbach alpha coefficient of the whole scale was calculated as .911.

Table 7. 22 Item-Total statistics.

\begin{tabular}{ccccccc}
\hline $\begin{array}{c}\text { Item } \\
\text { Number }\end{array}$ & Mean & $\begin{array}{c}\text { Standard } \\
\text { Deviation }\end{array}$ & $\boldsymbol{N}$ & $\begin{array}{c}\text { Item-Total } \\
\text { (Pearson) }\end{array}$ & $\begin{array}{c}\text { Corrected Item- } \\
\text { Total } \\
\text { Correlation }\end{array}$ & $\begin{array}{c}\text { Cronbach Alpha if } \\
\text { Item Deleted }\end{array}$ \\
\hline 10 & 4.0887 & .85173 & 631 & $.567^{* *}$ & .544 & .742 \\
3 & 4.0238 & .88609 & 631 & $.611^{* *}$ & .589 & .740 \\
20 & 3.8906 & 1.02775 & 631 & $.535^{* *}$ & .505 & .741 \\
7 & 3.9445 & .92673 & 631 & $.614^{* *}$ & .591 & .740 \\
14 & 3.3930 & .92627 & 631 & $.602^{* *}$ & .578 & .740 \\
1 & 4.1696 & .96515 & 631 & $.529^{* *}$ & .501 & .741 \\
12 & 4.2076 & .87632 & 631 & $.514^{* *}$ & .489 & .743 \\
4 & 4.1553 & .89157 & 631 & $.510^{* *}$ & .484 & .742 \\
9 & 4.4184 & .87609 & 631 & $.430^{* *}$ & .401 & .744 \\
21 & 3.3613 & 1.03404 & 631 & $.684^{* *}$ & .661 & .737 \\
19 & 3.1030 & 1.07075 & 631 & $.611^{* *}$ & .584 & .738 \\
17 & 3.7385 & .97252 & 631 & $.597^{* *}$ & .572 & .740 \\
11 & 3.3265 & .96835 & 631 & $.669^{* *}$ & .647 & .738 \\
16 & 3.0444 & 1.12176 & 631 & $.529^{* *}$ & .497 & .740 \\
8 & 3.1331 & 1.07852 & 631 & $.595^{* *}$ & .567 & .739 \\
22 & 3.3946 & 1.02100 & 631 & $.716^{* *}$ & .695 & .736 \\
13 & 3.2425 & 1.12257 & 631 & $.651^{* *}$ & .625 & .737 \\
6 & 3.3597 & 1.04906 & 631 & $.625^{* *}$ & .599 & .738 \\
5 & 3.4786 & .93898 & 631 & $.620^{* *}$ & .597 & .740 \\
2 & 3.3391 & .91324 & 631 & $.635^{* *}$ & .613 & .739 \\
15 & 3.1189 & 1.04660 & 631 & $.619^{* *}$ & .593 & .738 \\
18 & 3.1300 & 1.17199 & 631 & $.558^{* *}$ & .526 & .739 \\
\hline Total & 79.0618 & 12.89805 & 631 & 1.000 & 1.000 & .911 \\
\hline & & & & & &
\end{tabular}

The Cronbach alpha values were calculated for the whole scale and its sub-factors. This value was found to be .911 for the whole scale; .899 for Self -Efficacy; .832 for Appreciation-Reward and .802 for Value of Learning Physics sub-factors (Table 8).

Table 8. The Cronbach Alpha values for whole scale and sub-factors.

\begin{tabular}{ccc}
\hline Sub-Factors & Item Number & Cronbach Alpha \\
\hline Self - Efficacy & $2,5,6,8,11,13,14,15,16,18,19,21,22$ & .899 \\
Appreciation-Reward & $1,4,9,12,20$ & .832 \\
Value of Learning Physics & $3,7,10,17$ & .802 \\
Total & $1-22$ & .911 \\
\hline
\end{tabular}

In order to determine the discrimination of the 22 items in the MSPL, the relationship between the lower and the upper groups was examined. The total score obtained from the scale was ranked from big to small. Then, two groups were identified as $27 \%$ lower (170 persons) and $27 \%$ upper (170 persons). The mean scores of each item and the scale were compared with the independent group t-test. When these values were examined, it was seen that there was a significant difference between the lower and upper groups at .000 level for each item $(\mathrm{p}<.001)$. It was also determined that the discrimination $(t)$ values of the items ranged between 7.422 and 20.691 for each item (Table 9).

Table 9. Results of Lower-Upper group difference based item analysis.

\begin{tabular}{|c|c|c|c|c|c|c|c|c|}
\hline $\begin{array}{c}\text { Item } \\
\text { Number }\end{array}$ & Group & $N$ & Mean & $\begin{array}{l}\text { Standard } \\
\text { Deviation }\end{array}$ & $\begin{array}{c}\text { Mean of } \\
\text { Standard Error }\end{array}$ & $t$ & $d f$ & $p$ \\
\hline \multirow{2}{*}{10} & Lower & 170 & 4.58 & .572 & .044 & \multirow{2}{*}{11.817} & \multirow{2}{*}{263.745} & \multirow{2}{*}{$.000^{*}$} \\
\hline & Upper & 170 & 3.51 & 1.033 & .079 & & & \\
\hline \multirow{2}{*}{3} & Lower & 170 & 4.62 & .521 & .040 & \multirow{2}{*}{13.679} & \multirow{2}{*}{246.751} & \multirow{2}{*}{$.000^{*}$} \\
\hline & Upper & 170 & 3.39 & 1.056 & .081 & & & \\
\hline \multirow{2}{*}{20} & Lower & 170 & 4.47 & .645 & .049 & \multirow{2}{*}{11.981} & \multirow{2}{*}{257.199} & \multirow{2}{*}{$.000^{*}$} \\
\hline & Upper & 170 & 3.21 & 1.216 & .093 & & & \\
\hline \multirow{2}{*}{7} & Lower & 170 & 4.54 & .626 & .048 & \multirow{2}{*}{14.174} & \multirow{2}{*}{269.917} & \multirow{2}{*}{$.000^{*}$} \\
\hline & Upper & 170 & 3.17 & 1.088 & .083 & & & \\
\hline \multirow{2}{*}{14} & Lower & 170 & 4.09 & .732 & .056 & \multirow{2}{*}{15.786} & \multirow{2}{*}{322.549} & \multirow{2}{*}{$.000^{*}$} \\
\hline & Upper & 170 & 2.68 & .914 & .070 & & & \\
\hline \multirow{2}{*}{1} & Lower & 170 & 4.67 & .530 & .041 & \multirow{2}{*}{11.028} & \multirow{2}{*}{227.461} & \multirow{2}{*}{$.000^{*}$} \\
\hline & Upper & 170 & 3.52 & 1.256 & .096 & & & \\
\hline \multirow{2}{*}{12} & Lower & 170 & 4.66 & .500 & .038 & \multirow{2}{*}{10.051} & \multirow{2}{*}{227.686} & \multirow{2}{*}{$.000^{*}$} \\
\hline & Upper & 170 & 3.67 & 1.181 & .091 & & & \\
\hline \multirow[b]{2}{*}{4} & Lower & 170 & 4.61 & .547 & .042 & \multirow{2}{*}{9.541} & \multirow{2}{*}{236.421} & \multirow{2}{*}{$.000^{*}$} \\
\hline & Upper & 170 & 3.64 & 1.199 & .092 & & & \\
\hline
\end{tabular}




\begin{tabular}{|c|c|c|c|c|c|c|c|c|}
\hline \multicolumn{9}{|c|}{ Table 9 (Continued) } \\
\hline \multirow{2}{*}{9} & Lower & 170 & 4.68 & .592 & .045 & \multirow{2}{*}{7.422} & \multirow{2}{*}{244.662} & \multirow{2}{*}{$.000^{*}$} \\
\hline & Upper & 170 & 3.91 & 1.217 & .093 & & & \\
\hline \multirow{2}{*}{21} & Lower & 170 & 4.15 & .694 & .053 & \multirow{2}{*}{17.734} & \multirow{2}{*}{302.291} & \multirow{2}{*}{$.000^{*}$} \\
\hline & Upper & 170 & 2.50 & .993 & .076 & & & \\
\hline \multirow{2}{*}{19} & Lower & 170 & 3.95 & .855 & .066 & \multirow{2}{*}{16.574} & \multirow{2}{*}{332.506} & \multirow{2}{*}{$.000^{*}$} \\
\hline & Upper & 170 & 2.31 & .973 & .075 & & & \\
\hline \multirow{2}{*}{17} & Lower & 170 & 4.38 & .585 & .045 & \multirow{2}{*}{14.064} & \multirow{2}{*}{260.636} & \multirow{2}{*}{$.000 *$} \\
\hline & Upper & 170 & 3.05 & 1.078 & .083 & & & \\
\hline \multirow{2}{*}{11} & Lower & 170 & 4.11 & .692 & .053 & \multirow{2}{*}{19.160} & \multirow{2}{*}{321.422} & \multirow{2}{*}{$.000 *$} \\
\hline & Upper & 170 & 2.48 & .872 & .067 & & & \\
\hline \multirow{2}{*}{16} & Lower & 170 & 3.86 & .950 & .073 & \multirow{2}{*}{13.857} & \multirow{2}{*}{335.509} & \multirow{2}{*}{$.000^{*}$} \\
\hline & Upper & 170 & 2.36 & 1.036 & .079 & & & \\
\hline \multirow{2}{*}{8} & Lower & 170 & 3.93 & .833 & .064 & \multirow{2}{*}{16.722} & \multirow{2}{*}{328.375} & \multirow{2}{*}{$.000^{*}$} \\
\hline & Upper & 170 & 2.27 & .990 & .076 & & & \\
\hline 22 & Lower & 170 & 4.22 & .620 & .048 & 20691 & 292438 & 000* \\
\hline 22 & Upper & 170 & 2.43 & .941 & .072 & 20.691 & 292.438 & .000 \\
\hline 13 & Lower & 170 & 4.09 & .776 & .059 & 19540 & 317900 & $000 *$ \\
\hline 13 & Upper & 170 & 2.19 & 1.003 & .077 & 19.540 & $31 / .904$ & $.000^{\circ}$ \\
\hline 6 & Lower & 170 & 4.16 & .716 & .055 & & & \\
\hline 0 & Upper & 170 & 2.50 & 1.022 & .078 & 17.331 & 302.768 & $.000^{*}$ \\
\hline 5 & Lower & 170 & 4.17 & .738 & .057 & 15251 & 21065 & ก००* \\
\hline כ & Upper & 170 & 2.77 & .942 & .072 & 15.251 & כ5 & .000 \\
\hline 2 & Lower & 170 & 4.01 & .701 & .054 & 15203 & 314.965 & $000 *$ \\
\hline 2 & Upper & 170 & 2.65 & .925 & .071 & 13.203 & 314.905 & $.000^{\circ}$ \\
\hline 15 & Lower & 170 & 3.94 & .786 & .060 & 17160 & 327678 & ก0०* \\
\hline 15 & Upper & 170 & 2.29 & .940 & .072 & 17.469 & $321.6 / 8$ & $.000^{\circ}$ \\
\hline 18 & Lower & 170 & 3.94 & .955 & .073 & 621 & 336.469 & $000 *$ \\
\hline 10 & Upper & 170 & 2.26 & 1.022 & .078 & $0<1$ & & .000 \\
\hline Total & Lower & 170 & 93.8059 & 6.22773 & .47764 & 0717 & 207757 & ก0०* \\
\hline Total & Upper & 170 & 62.7529 & 8.07056 & .61898 & $39 . / 1 /$ & 317.582 & .000 \\
\hline
\end{tabular}

Test-retest was performed with 42 (36 girls, 6 boys) second-year pre-service science teachers who were enrolled in the department of science education in a state university education faculty in Istanbul in the 2018-2019 academic year. The same test was repeated 15 days later in the same group. Correlation values were calculated for each factor and presented in Table 10. According to the results of this analysis, it was seen these values varied between .507 and .832 . The fact that values were close to 1 indicates the MSPL has a reliable and stable structure.
Table 10. Test re-test correlation coefficients of whole scale and sub-factors

\begin{tabular}{cc}
\hline Sub-Factors & $r$ \\
\hline Self - Efficacy & .832 \\
Appreciation-Reward & .645 \\
Value of Learning Physics & .507 \\
\hline Total & .863 \\
\hline
\end{tabular}

Sample items of MSPL are presented in Table 11. The scale is given in both English and Turkish in Appendix 1.

Table 11. Some items of MSPL.

\begin{tabular}{cc}
\hline Item Number & Items \\
\hline $\mathbf{8}$ & Even if I encounter a question about physics that I have never seen before, I think \\
that I can solve it. (Self efficacy) \\
$\mathbf{1 8}$ & I like being in a race with my friends in physics classes. (Self efficacy) \\
$\mathbf{9}$ & I'd like to get high marks in physics. (Appreciation reward) \\
$\mathbf{1 0}$ & Learning physics helps us to produce the creative ideas about the world. (Value of \\
& learning physics) \\
$\mathbf{1 7}$ & I think about physics in everyday life. (Value of learning physics) \\
\hline
\end{tabular}

\section{Conclusion}

In this study, the aim was to develop a valid and reliable measurement tool to measure the motivation levels of pre-service science teachers enrolled at the studying level for physics learning. The 682 pre-service science teachers were enrolled in the science education department of 6 public universities education faculty in Turkey from 1st, 2nd, 3rd, and 4th year in the 2017-2018 academic year. It was determined that the measuring tool had a three-factor structure consisting of 22 items. It was found that the total variance explained by the factors was $53.448 \%$, and the load values of the items in the factor ranged between . 555 and .821 . The results of CFA were supported by the structure obtained from the EFA, and the fit indices were found to be excellent or acceptable. For the reliability of the scale, the Cronbach alpha coefficient was examined, and test-retest was performed. As a result of the reliability analysis, the Cronbach alpha coefficient was found to be .911 for the whole scale; .899 for Self - Efficacy; .832 for Appreciation-Reward and .802 for Value of Learning Physics sub-factors. The Test-retest results showed a positive correlation between the sub-factors. For the item discrimination of the MSPL,a lower-upper group analysis was carried out, and it was seen that MSPL had a valid, reliable and stable structure. 
When the literature was examined, it was seen that most of the studies carried out for motivation towards learning science were scale adaptation studies (Yılmaz \& Çavaş, 2007; Ekici, 2009; Güvendik, 2010; İlhan et al., 2012; Tosun, 2013; Dermitzaki et al., 2013; Mubeen \& Reid, 2014; Çetin Dindar \& Geban, 2015; Erdoğan et al., 2015; Liu et al., 2017). Scale development studies for motivation towards learning science have been performed by Tuan et al. (2005), Dede \& Yaman (2008), Gylnn et al. (2009, 2011), Aydın et al. (2014), Fortus and Vedder-Weiss (2014), Önen and Ulusoy (2014), Rodil (2014), Eskicioğlu and Alpat (2017) and Özdemir et al. (2018). When the areas of the developed or adapted scales were examined, it could be seen there were a limited number of measurement tools for physics learning and these measurement tools were limited to the secondary education level, and there were no measurement tools for measuring the motivation towards learning physics at the university level. Among the developed motivation scales, only Özdemir et al. (2018) constructed a motivation scale for physics learning. However, it was seen that this scale was developed for the high school level.

In the study by Özdemir et al. (2018), 38 items and a seven-factor structure were reached. In the study by Özdemir et al. (2018); it was seen that the factors were self-efficacy, the value of learning physics, effective learning strategies, achievement goals, learning environment encouragement, communication, and collaborative work, and research on physics. In this study, motivation factors for physics learning are self-efficacy, appreciation-reward and the value of physics learning. In this context, it is thought that the motivation factors may be different for learning physics for high school students and university students.

Tuan et al. (2005), Yilmaz and Çavaş (2007), We Trusted (2010), Glynn et al. (2011), İlhan et al. (2012), Tosun (2013), Çetin Dindar and Geban (2015), Dermitzaki et al. (2013) and Özdemir et al. (2018) identified self-efficacy as a sub-dimension, as we found in our study. Önen and Ulusoy (2014), Dermitzaki et al. (2013), Yılmaz and Çavaş (2007), Tuan et al. (2005) and Özdemir et al. (2018) determined the value of learning physics as a sub-dimension in their own studies as in this study.

\section{Limitations and Future Work}

This study was limited to undergraduate pre-service science teachers to determine their motivation levels on physics learning. The sub-factor of appreciation-reward can be seen as an external stimulus in the motivation theory. However, this sub-dimension was not found in the studies conducted in recent years. In this respect, the original contribution to the literature was the presence of the Appreciation-Reward sub-factor as a sub-dimension that affected motivation towards physics learning in this research.

The findings suggest that MSPL is a good measurement tool that researchers, instructors, and academic advisors can use to efficiently assess students' motivation to learn physics in universities at different divisions.
As it is known, physics courses at the university level are fundamental courses in all departments of science, medicine and engineering. In this context, the Motivation Scale towards Physics Learning can be used to determine the motivation levels of students studying in these fields at the university level for physics learning for pre-services. The enrichment of the sample will make a significant contribution to the literature in terms of revealing the differences or similarities between the participants. Following the determination of the motivation levels of the students at the university level for learning physics, studies can be carried out to determine the changes in the motivation levels by using appropriate teaching strategies and methods to increase the physics attitudes and physics achievement. When the literature is examined, there are studies in which motivation varies according to many demographic variables. Using this measurement tool, we can be investigate whether the motivation level for learning physics differs according to demographic variables.

\section{Declaration of Conflict of Interests}

The authors have no competing interests to declare.

\section{References}

Ames, C. A. (1990). Motivation: What teachers need to know. Teacher's College Record, 91(3), 409-421.

Angell, C., Guttersrud, Ø., Henriksen, E. K., \& Isnes. A. (2004). Physics: Frightful, but fun, Pupils' and teachers' views of Physics and Physics teaching. Science Education, 88(5), 683-706. https://doi.org/10.1002/sce.10141

Arseven, A. (2016). Self-efficacy: A concept analysis. Turkish Studies, 11(19), 63-80. http://dx.doi.org/10.7827/TurkishStudies.10001

Aydın, S., Yerdelen, S., Yalmanc1, S.G., \& Göksu. V. (2014). Academic Motivation Scale for Learning Biology: A Scale Development Study. Education and Science, 39(176), 425-435. http://dx.doi.org/10.15390/EB.2014.3678

Bandura, A.(1977). Self-efficacy: Toward a unifying theory of behavioral change. Psychological Review, 84(2), 191-215. https://doi.org/10.1037/0033-295X.84.2.191

Boekaerts, M., \& Simons, P. R. J. (1995). Learning and instruction: The psychology of the student and the learning process. (2nd, revised version ed.). Assen: Van Gorcum.

Brophy, J. (1987). On motivating students. East Lansing, MI: Michigan State University.

Cannon, R.K., \& Simpson, R.D. (1985). Relationships among attitude, motivation and achievement of ability grouped, seventh-grade, life science students. Science Education, 69(2), 121-138. https://doi.org/10.1002/sce.3730690203

Cebesoy, Ü.B. (2013). Pre-Service Science Teachers' Perceptions of Self-Regulated Learning in Physics. Turkish Journal of Education, 2(1), 4-18

Crump, C.A. (1995). Motivating Students: A Teacher's Challenge. Annual Sooner Communication Conference. Norman, $\mathrm{OK}$

Colclough, N. D., Lock, R., \& Soares, A. (2010). Pre-service Teachers' Subject Knowledge of and Attitudes about Radioactivity and Ionising Radiation. International Journal of Science Education, 33(3), 423-446. https://doi.org/10.1080/09500691003639905

Cetin Dindar, A., \& Geban, Ö. (2015). Adaptation of the Science Motivation Scale into Turkish and Chemistry: Analysis of Validity. Pegem Journal of Education and Training, 5(1), 15-34. 
De Lozano, S. R., \& Cardenas, M. (2002). Some learning problems concerning the use of symbolic language in physics. Science and Education, 11(6), 589-599. https://doi.org/10.1023/A:1019643420896

Dede, Y., \& Yaman, S. (2008). A Questionnaire for Motivation toward Science Learning: A Validity and Reliability Study. Necatibey Faculty of Education Electronic Journal of Science and Mathematics Education, 2(1), 19-37.

Dermitzaki, I., Stavroussi, P., Vavougios, D., \& Kotsis, K.T. (2013). Adaptation of the Students' Motivation towards Science Learning (SMTSL) questionnaire in the Greek language. European Journal of Psycbology of Education, 28(3), 747-766. https://doi.org/10.1007/s10212-012-0138-1

Ekici, G. (2009). Adaptation of the biology motivation questionnaire to Turkish. Journal of Contemporary Education, 34(365), 6-15.

Elmas, R. (2012). The effect of context based instruction on 9 th grade students' understanding of cleaning materials topic and their attitude toward environment. Unpublished doctoral dissertation, Middle East Technical University, Ankara.

Erdoğan, D., Çakır, M., Gürel, C. \& Şeker, H. (2015). Validity and Reliability Study of the Turkish Version of Continuing Motivation for Science Learning Scale. Trakya University Journal of Education Faculty, 5 (2), 125-136.

Eren, E. (2004). Organizational Behavior and Management Psychology. İstanbul: Beta.

Eskicioğlu, A., \& Alpat, S. (2017). Development of Chemistry Lesson Motivation Scale for Secondary School Students. Journal of Turkish Chemical Society, 2 (2), 185-212.

Field, D. (2000). Qualitative measures for initial meshes. Numerical Mothods in Engineering, 47(4), 88-906.

Fishbane, P. M., Gasiorowicz, S., \& Thornton, S .T. (1996). Physics for Scientists and Engineers (2nd ed.). Upper Saddle River, New Jersey: Prentice Hall.

Fortus, D., \& Vedder-Weiss, D. (2014). Measuring students' continuing motivation for science learning. Journal of Research in Science Teaching, 51(4), 497-522. https://doi.org/10.1002/tea.21136

Gage, N. L., \& Berliner, D. C. (1992). Educational Psychology (5th ed.). Boston, MA, US: Houghton, Mifflin and Company.

Glynn, M. S., \& Koballa, T. R. (2006). Motivation to Learn College Science. (Ed.; J. J. Mintzes and W. H. Leonard), Handbook of college science teaching. Arlington: VA.

Glynn, M. S., Taasoobshirazi, G., \& Brickman, P. (2009). Science motivation questionnaire: construct validation with nonscience majors. Journal of Research in Science Teacbing, 46 (2), 127-146. https://doi.org/10.1002/tea.20267

Glynn, M. S., Brickman, P., Armstrong, N., \& Taasoobshirazi, G. (2011).Science motivation questionnaire II: Validation with science majors and nonscience majors. Journal of Research in Science Teacbing, 48(10), 1159-1176. https://doi.org/10.1002/tea.20442

Guido, R. M. (2013). Attitude and motivation towards learning physics. International Joumal of Engineering Research and Technology, 2(11), 2087-294.

Güvendik, F. (2010). The adaptation of the chemistry motivation questionnaire and the investigation of the questionnaire's structure reliability. Unpublished master's thesis. Gazi University, Ankara.

Hammer, D., \& Elby, A. (2003). Tapping epistemological resources for learning physics. Journal of the Learming Sciences, 12(1), 53-90. https://doi.org/10.1207/S15327809JLS1201_3

Henson, R. K., \& Roberts, J. K. (2006). Use of exploratory analysis in published research: common errors and some comments on improved practice. Educational and Psychological Measurement, 66(3), 393-416. https://doi.org/10.1177/0013164405282485

Horn, T. (2000). Intrinsic motivation relationships with collegiate athletes gender, scholarship status, and perceptions of their coaches behavior. Journal of sport \& exercise psychology, 22(1), 63-84.

Hu, L., \& Bentler, P. M. (1999). Cutoff criteria for fit indexes in covariance structure analysis: Conventional criteria versus new alternatives. Structural Equation Modeling, 6(1), 1-55. https://doi.org/10.1080/10705519909540118
Hutcheson, G., \& Sofroniou, N. (1999). The Multivariate Social Scientist: Introductory Statistics Using Generalized Linear Models. Sage Publication: Thousand Oaks, CA.

Klassen, R. M., Bong, M., Usher, E. L., Chong, W. H., Huan, V. S., Wong, I. Y. F., \& Georgiou, T.(2009). Exploring the validity of a teachers' self-efficacy scale in five countries. Contemporary Educational Psychology, 34(1), 67-76. https://doi.org/10.1016/j.cedpsych.2008.08.001

İhan, N., Ylldırm, A., \& Yllmaz, S. S. (2012). Chemistry motivation questionnaire: the study of validity and reliability. Mustafa Kemal University Journal of Social Sciences Institute, 9(18), 297-310.

Lai, C. (2018). Using inquiry-based strategies for enhancing students' STEM education learning. Journal of Education in Science, Environment and Health, 4(1), 110-117. https://doi.org/10.21891/jeseh.389740

Liu, Y., Ferrell, B., Barbera, J., \& Lewis, J.E. (2017). Development and evaluation of a chemistry-specific version of the Academic Motivation Scale (AMS-Chemistry). Chemistry Education Research and Practice, 18, 191-213.

Lynch, D.J. (2006). Motivational factors, learning strategies and resource management as predictors of course grades. College Student Journal, 40(2), 423-428.

Lynch, D.J. (2010). Motivational beliefs and learning strategies as predictors of academic performance in college physics. College Student Journal, 44(4), 920-928.

MacCallum, R. C., Browne, M. W., \& Sugawara, H.M. (1996). Power analysis and determination of sample size for covariance structure modeling. Psychological Method, 1(2), 130-149. https://doi.org/10.1037/1082-989X.1.2.130

Marsh, H. W., \& Hocevar, D. (1985). Application of Confirmatory Factor Analysis to the Study of Self-Concept. Firstand Higher Order Factor Models and Their Invariance Across Groups. Psychological Bulletin, 97(3), 562-582. https://doi.org/10.1037/0033-2909.97.3.562

Maslow, A.H. (1984). A theory of human motivation. American Psychological Association, Psychological Review, 50(4), 370-396. https://doi.org/10.1037/h0054346

Ministry of Education. (2019). http://mufredat.meb.gov.tr/Programlar.aspx

Mubeen, S., \& Reid, N. (2014). The Measurement of motivation with science students. European Journal of Educational Research, 3 (3), 129-144. 10.12973/eu-jer.3.3.129

Önen, S. A., \& Ulusoy, F. M. (2014). Developing the context-based chemistry motivation scale: validity and reliability analysis. Journal of Baltic Science Education, 13 (6), 809-820.

Özdemir, E., Kural, M., \& Kocakülah, M.S. (2018). Developing a Scale to Measure Secondary School Students' Motivation. Kastamonu Education Journal, 26 (5), 1497-1507.

Pallant, J. (2001). SPSS Survival Manual. A step-by-step Guide to Data Analysis Using SPSS for Windows. New South Wales, Australia: Allen \& Unwin.

Parham, A. C. (1988). Psychology: Studying the behavior of people. Cincinnati, Ohio: South-Western Publishing.

Pekdağ, B., Azizoğlu, N., Topal, F., Ağalar, A., \& Oran, E. (2013). The effect of academic achievement on the level of associating chemistry knowledge with everyday situations. Kastamonu Education Journal, 21(4), 1275-1286.

Peklaj, C., \& Levpuscek, M. P. (2006). Student motivation and academic success in relation to the quality of individual and collaborative work during a course in educational psychology. 31. Association of Teacher Education in Europe: ATTE.

Pintrich, P. R., \& Schunk, D. H. (1996). Motivation in education: Theory, research, and application. NJ: Prentice-Hall.

Pintrich, P. R., \& Schunk, D.H. (2002). Motivation in education: Theory, research, and applications (2nd edition). NJ: Pearson: Merrill Prentice Hall.

Richards, J. C., Platt, J. H., \& Platt, H. (1992). Language teaching and applied linguistics. London: Longman.

Rodil, M. S. P. (2014). Development and validation of an inventory that measures motivated behavior in chemistry. Journal of Education and Practice, 5 (34), 79-85. 
Ruthankoon, R., \& Ogunlana, S. O. (2003). Testing Herzberg's two-factor theory in the thai construction. Engineering. Construction and Arcbitectural Management, 10 (5), 333-341. http://dx.doi.org/10.1108/09699980310502946

Ryan, R. M., Stiller, J. D., \& Lynch, J. H. (1994). Representations of relationships to teachers, parents, and friends as predictors of academic motivation and self-esteem. The Journal of Early Adolescence, 14(2), 226-249. https://doi.org/10.1177/027243169401400207

Ryan, R. M., \& Deci, E. L. (2000a). Intrinsic and Extrinsic Motivations: Classic Definitions and New Directions. Contemporary Educational Psychology, 25(1), 54-67. https://doi.org/10.1006/ceps.1999.1020

Saleh, S. (2014). Malaysian Students' Motivation towards Physics Learning. European Journal of Science and Mathematics Education, 2(4), 223-232.

Schunk, D. H. (2012). Learning theories: an educational perspective. Boston: Pearson.

Seçer, I. (2015). Psychological test development and adaptation process. Ankara: Anı Yayıncillk.

Singh, K., Graville, M., \& Dika, S. (2002). Mathematics and science achievement: Effects of motivation interests and academic engagement. Journal of Educational Research, 95(6), 323-332. https://doi.org/10.1080/00220670209596607

Schiefele, U., Krapp, A., \& Schreyer, I. (1993a). Metaanalyse des Zusammenhangs von Interesse und schulischer Leistung [A metaanalysis concerning the relation between interest and achievement in school]. Zeitsr fiir Entwicklungspsychologie und Pddagogischer Psychologic, 25(2), 120-148.

Smith, M. U., \& Siegel, H. (2004). Knowing, believing, and understanding: What goals for science education. Science Education, 13, 553-582. https://doi.org/10.1023/B:SCED.0000042848.14208.bf

Stylianides, A. J., \& Stylianides, G. J. (2008). Studying the implementation of tasks in classroom settings: High-level mathematics tasks embedded in "real-life" contexts. Teaching and Teacher Education, 24, 859-875.

Sümer, N. (2000). Structural equation models. Turkish Psychology Articles, 3(6), $49-74$.

Şimşek, Ö. F. (2007). Introduction to structural equation modeling. Ankara: Ekinoks.

Tohidi, H., \& Jabbari, M. M. (2012). The effects of motivation in education. Social and Behavioral Sciences, 31, 820-824. https://doi.org/10.1016/j.sbspro.2011.12.148

Tosun, C. (2013). Adaptation of Chemistry Motivation Questionnaire-II to Turkish: A Validity and Reliability Study. Journal of Erzincan University Faculty of Education, 15 (1), 173-202.

Tuan, H. L., Chin, C. C., \& Shieh, S. H. (2005). The development of a questionnaire to measure students' motivation towards science learning. International Journal of Science Education, 27(6), 639-654. https://doi.org/10.1080/0950069042000323737

Urdan, T. (1997). Achievement goal theory: past results, future directions. In M.L. Maehr \& P.R. Pintrich (Eds.), Advances in motivation and achievement, (Vol. 10). Greenwich, CT: JAI Press; 99-141.

Watters, J. J., \& Ginns, I. S. (2000). Developing motivation to teach elemantary science: effect of collaborative and authentic learning practices in preservice education. Journal of Science Teacber Education, 11 (4), 277-313. https://doi.org/10.1023/A:1009429131064

Yılmaz, H., \& Çavaş, P. (2007). Reliability and Validity Study of the Students' Motivation toward Science Learning (SMTSL) Questionnaire. Elementary Education Online, 6(3), 430-440. 


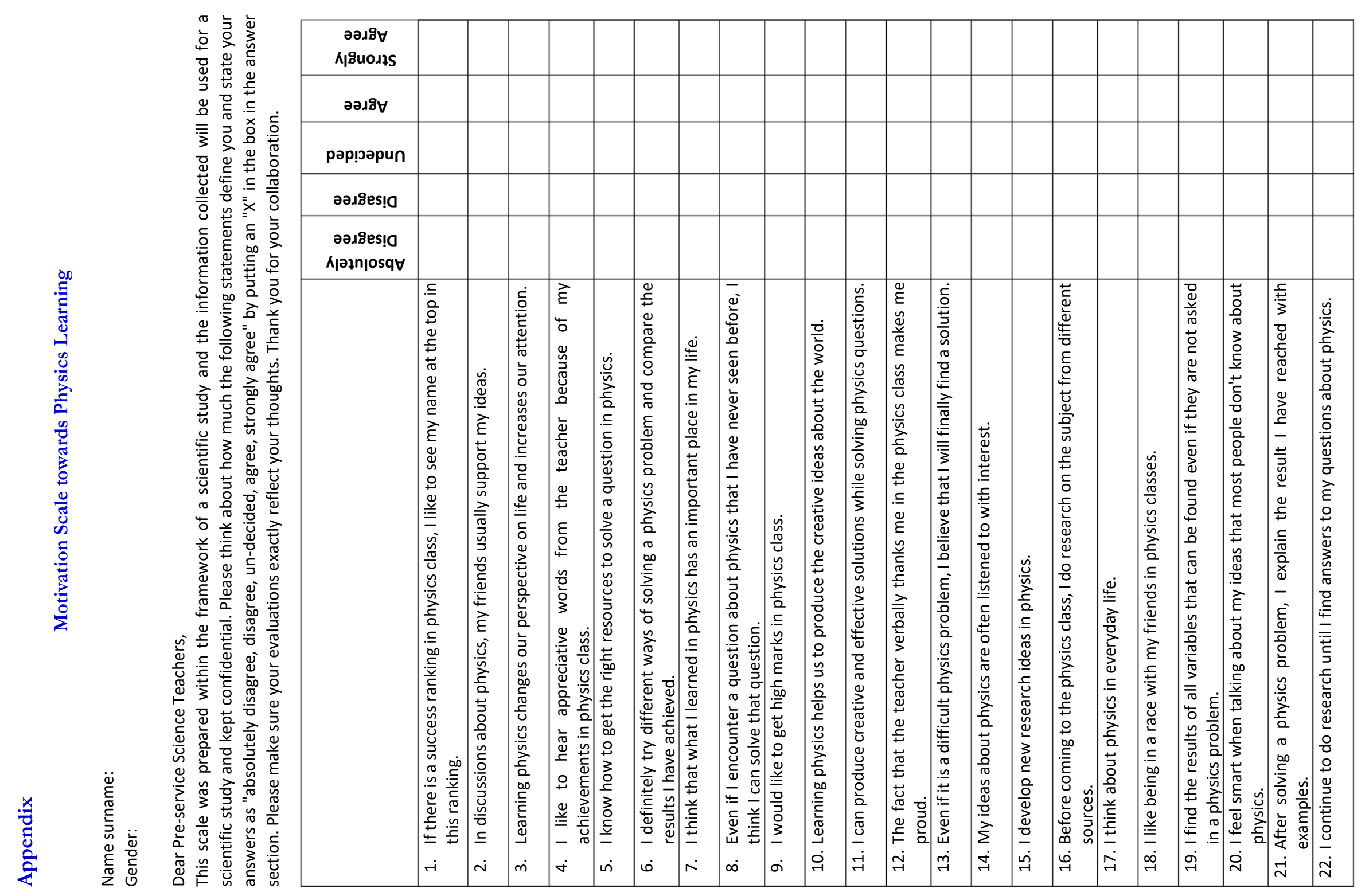




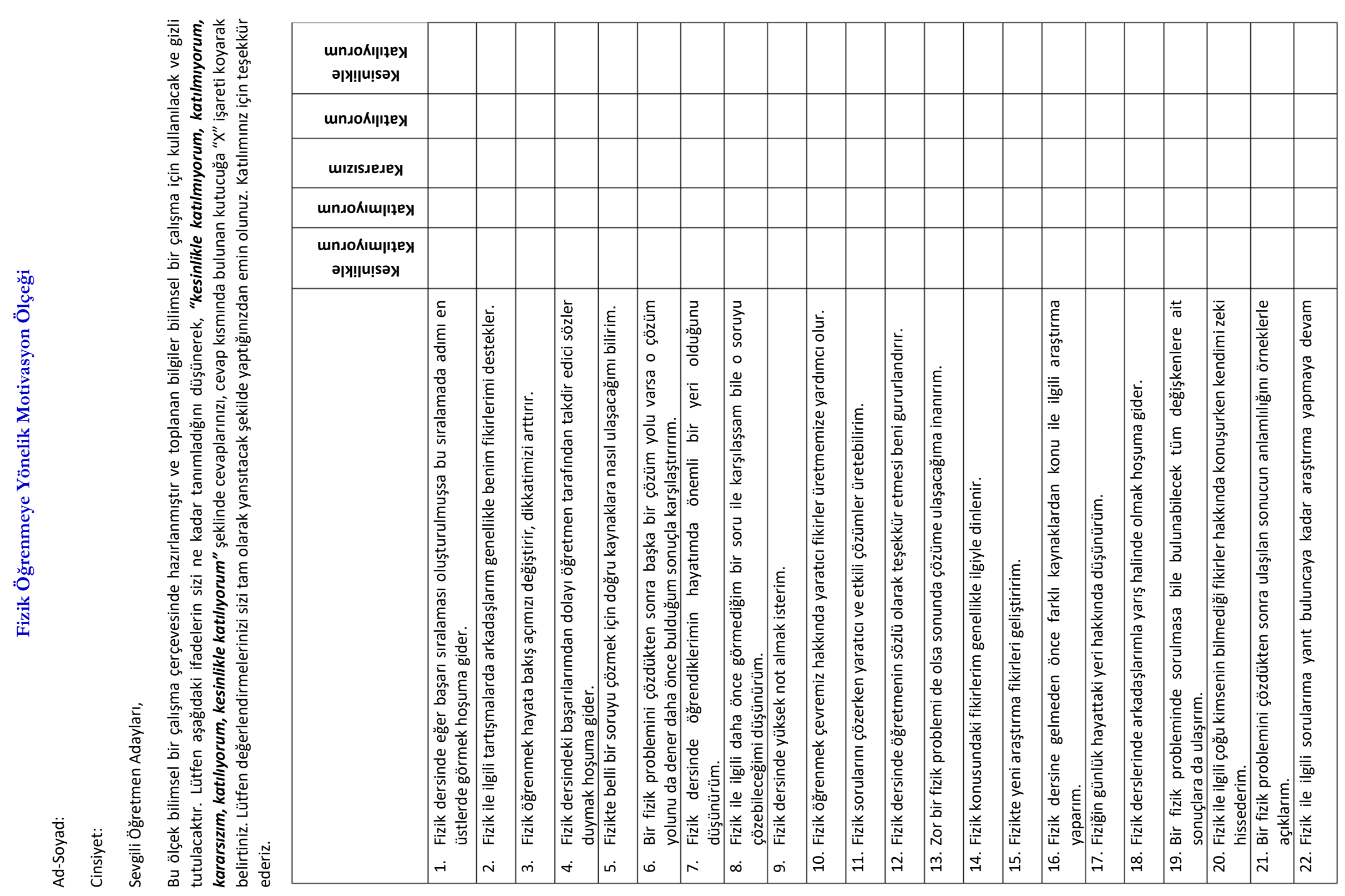

